\title{
Comparison of Natural Frequencies Values of Circular Saw Blade Determined by Different Methods
}

\section{Usporedba vrijednosti vlastitih frekvencija lista kružne pile određenih različitim metodama}

\author{
Preliminary paper • Prethodno priopćenje \\ Received-prispjelo: 12. 3. 2013. \\ Accepted-prihvaćeno: 20. 5. 2015. \\ UDK: $630 * 822.02 ; 630 * 822.331 .6$ \\ doi:10.5552/drind.2015.1316
}

\begin{abstract}
In most cases high cutting speed is used when cutting wood by circular saw. This results in oscillating of circular saw blade, which may lead to destroying the tool, machine or hurting the operator. The aim of this paper is to show that it is possible to apply any of the methods used in the research as an equivalent method for obtaining the values of natural frequencies of circular saw blade. The article deals with three methods for obtaining the values of natural frequencies. The first method is modal analysis, the second method is the determination of values measured experimentally and the last method calculates the values by Bessel functions. A circular saw blade was used with the diameter of $350 \mathrm{~mm}$ and 36 teeth on the blade.
\end{abstract}

Key words: circular saw blade, critical rotational speed, natural frequencies, finite element method

SAŽETAK • Tijekom rezanja drva kružnim pilama vrlo se često primijenjuje velika brzina rezanja, što uzrokuje oscilacije lista kružne pila te katkad može rezultirati uništavanjem alata odnosno stroja ili dovesti do ozljede radnika. Cilj je ovoga rada prikazati mogućnosti primjene različitih metoda za određivanje vrijednosti vlastitih frekvencija lista kružne pile. U članku se prikazuje primjena triju metoda za određivanje vrijednosti vlastitih frekvencija lista kružne pile. Prva je metoda modalna analiza, druga je metoda eksperimentalno određivanje vlastitih frekvencija uz pomoć mjernog uređaja, a treća je metoda izračunavanje vrijednosti frekvencija s pomoću Besselovih funkcija. U eksperimentu je upotrijebljen list kružne pila promjera $350 \mathrm{~mm} \mathrm{~s} 36 \mathrm{zubi}$.

Ključne riječi: list kružne pile, kritična brzina vrtnje, vlastite frekvencije, metoda konačnih elemenata

\section{INTRODUCTION}

1. UVOD

Circular saw dynamic features such as workpiece characteristics, circular saw blade accuracy, and static and dynamic properties of the tool influence the accu- racy of sawing, surface roughness, operating noise level, tool life, etc.

As the circular saw blade is the most common device for cutting wood and wood based materials in the wood industry, it is important to deal with the problem of oscillation of circular saw blade. Vibrations are

\footnotetext{
${ }^{1}$ Authors are associate professor, associate professor, PhD student and assistant at Faculty of Environmental and Manufacturing Technology, Technical University in Zvolen, Zvolen, Slovak Republic.

${ }^{1}$ Autori su izvanredni profesor, izvanredni profesor, doktorand i asistent Fakulteta okolišne i proizvodne tehnologije, Tehničko sveučilište u Zvolenu, Zvolen, Slovačka.
} 


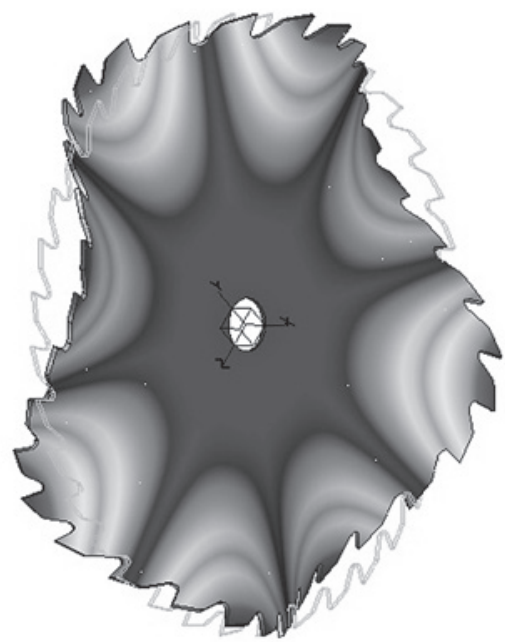

Figure 1 Model of circular saw blade by modal analysis in deformed state $(n=4 ; m=0 ; f=439.45 \mathrm{~Hz})$

Slika 1. Model lista kružne pile u deformiranom stanju dobiven modalnom analizom $(n=4 ; m=0 ; f=439,45 \mathrm{~Hz})$

emitted during the cutting process and when the critical rotational speed is reached, the circular saw blade becomes unstable. So the reduction of the amplitude of oscillations is essential for improving the parameters such as surface quality, precision of cutting, increase of the yield and longer tool life, but also for reducing noise. Therefore, it is necessary to find solutions to eliminate these adverse effects.

There are many methods for determining natural frequencies (the next step is to calculate critical rotational speed). The values calculated using various equations do not give an idea of how the circular saw blade behaves. For better understanding, a software program was used in this paper that displays the deformation of the circular saw blade as a result of oscillation. The results of circular saw blade static modal analysis (for nodal diameter $n=4$, and nodal circles $m=0$ ) is shown in Figure 1.

Instability of circular saw blade was the subject of many scientific studies. Many scientists dealt with experimental methods of circular saw blade oscillation (Mote, 1965; Pahlitzsch and Rowinski, 1966; Stakhiev, 1970, 1998, 2000; Schajer and Mote, 1983; Yu and Mote, 1987; Nishio and Marui, 1996; Siklienka and Svoren̆, 1997; Orlowski et al., 2007; Javorek, L. et al., 2010; Veselý et al., 2012). Some authors studied the application of the finite element method using different software programs to determine the oscillation of saw blade (Gogu, 1988; Holфyen, 1987, Leopold and Münz, 1992; Michna and Svoreň, 2007; Ekevad et al., 2009). The analytical solution that uses the Bessel function was studied by Southwell (1922) and Kirshoff (1982).

\section{MATERIAL AND METHODS} 2. MATERIJAL I METODE

In practice, one of the most important questions is how to evaluate the critical rotational speed of circu- lar saw blade. To solve this problem, it is necessary to determine the values of natural frequencies. The parameters of the circular saw blade used in this paper are shown in Table 1.

Table 1 Parameters of the circular saw blade

Tablica 1. Parametri lista kružne pile

\begin{tabular}{|l|c|}
\hline Outer diameter / Vanjski promjer & $350 \mathrm{~mm}$ \\
\hline Inner diameter / Unutarnji promjer & $30 \mathrm{~mm}$ \\
\hline Number of teeth / Broj zubiju & 36 \\
\hline Thickness of body / Debljina & $2.4 \mathrm{~mm}$ \\
\hline Height of tooth / Visina zuba & $13 \mathrm{~mm}$ \\
\hline
\end{tabular}

For clamping circular saw blade, clamping collars were used with the diameter $d_{c}=110 \mathrm{~mm}$.

This paper considers three methods for obtaining the values of natural frequencies:

- Bessel functions

- FEM (academic version ProEngineer WF 4)

- Experimental measurement.

\subsection{Bessel functions}

\subsection{Besselove funkcije}

Differential equation of vibration of circular saw blade can be expressed as follows (Benhao, et al. 2009):

$$
\begin{aligned}
& \left(\frac{\partial^{2}}{\partial r^{2}}+\frac{1}{r} \cdot \frac{\partial}{\partial r}+\frac{1}{r^{2}} \cdot \frac{\partial^{2}}{\partial \theta^{2}}\right) \\
& \cdot\left(\frac{\partial^{2}}{\partial r^{2}}+\frac{1}{r} \cdot \frac{\partial}{\partial r}+\frac{1}{r^{2}} \cdot \frac{\partial^{2}}{\partial \theta^{2}}\right) W(r, \theta, t)+\frac{\rho \cdot h}{D} \cdot \ddot{W}=0
\end{aligned}
$$

Here, the bending stiffness of the blade is:

$$
D=\frac{E \cdot h^{3}}{12 \cdot\left(1-v^{2}\right)}
$$

Where:

$h$-thickness of circular saw blade / debljina lista kružne pile, $\mathrm{mm}$

$E$ - modulus of elasticity / modul elastičnosti, $\mathrm{N} \cdot \mathrm{m}^{-2}$ $\left(E=2.1 \times 10^{11}\right)$

$n$ - Poisson ratio / Poissonov omjer $(n=0.33)$.

The differential equation is solved by separation of variables. The resulting function can be written in the form:

$$
W(r, \theta, t)=w(r, \theta) \cdot e^{i \cdot \omega \cdot t}=R(k r) \cdot \cos n \cdot \theta \cdot e^{i \cdot \omega \cdot t}
$$

Where:

$n$-number of nodal diameters / broj čvornih promjera.

Function $R(k, r)$ is solved by Bessel functions.

$R(k, r)=A_{n} J_{n}(k, r)+B_{n} N_{n}(k, r)+C_{n} I_{n}(k, r)+D_{n} K_{n}(k, r)(4)$

Where: $k^{4}=\frac{\rho \cdot h}{D}$

$r$ - density / gustoća, $\mathrm{kg} \cdot \mathrm{m}^{-3}\left(r=7800 \mathrm{~kg} \cdot \mathrm{m}^{-3}\right)$

$J_{n}$ - the Bessel function of the first kind of order $n$ / Besselova funkcija prve vrste reda $n$

$N_{n}$ - the Bessel function of the second kind of order $n$ / Besselova funkcija druge vrste reda $n$ 
$I_{n}$ - the modified Bessel function of the first kind of order $n$ / modificirana Besselova funkcija prve vrste reda $n$

$K_{\mathrm{n}}$ - the modified Bessel function of the second kind of order $n$ / modificirana Besselova funkcija druge vrste reda $n$

$A_{n^{\prime}} B_{n^{\prime}}, C_{n^{\prime}}, D_{n}$ are (to be) determined constants/utvrđene konstante.

After the theoretical solution, the formula obtained for natural frequency was:

$$
\omega=\frac{h}{D^{2}} \cdot \sqrt{\frac{E \cdot \alpha}{12 \cdot \rho \cdot(1-v)}}
$$

Where

$D$ - diameter of circular saw blade / promjer lista kružne pile, $\mathrm{mm}$

$\alpha$ - coefficient (depending on $n$ and clamping ratio) / koeficijent (ovisan o $n$ i o omjeru pričvršćenja lista)

Natural frequency can be expressed by the following formula:

$$
f=\frac{\omega}{2 \cdot \pi}
$$

\subsection{Modal analyses \\ 2.2. Modalna analiza}

Pro/Engineer WF4 software with FEM module was used for the theoretical modal analysis. The values of natural frequencies were obtained for $n=1,2,3,4$ in static modal analysis. The parameters for computing by FEM were: clamping diameter - $110 \mathrm{~mm}$ (absolutely rigid); outer diameter of the model - $350 \mathrm{~mm}$; number of teeth -36 .

The resulting values of modal analysis are influenced by various parameters (material, type of model mesh, number of elements, etc). Five modal analyses were made with different element sizes. In the modal analysis Shell 5, shell elements of the model were used with the maximum size of $5 \mathrm{~mm}$. In the modal analysis Shell 10, shell elements of the model were used with the maximum size of $10 \mathrm{~mm}$ and in the modal analysis Shell 20, the maximum element size was $20 \mathrm{~mm}$. The density of circular saw blade mesh for modal analysis Shell 10 is shown in Fig. 2.
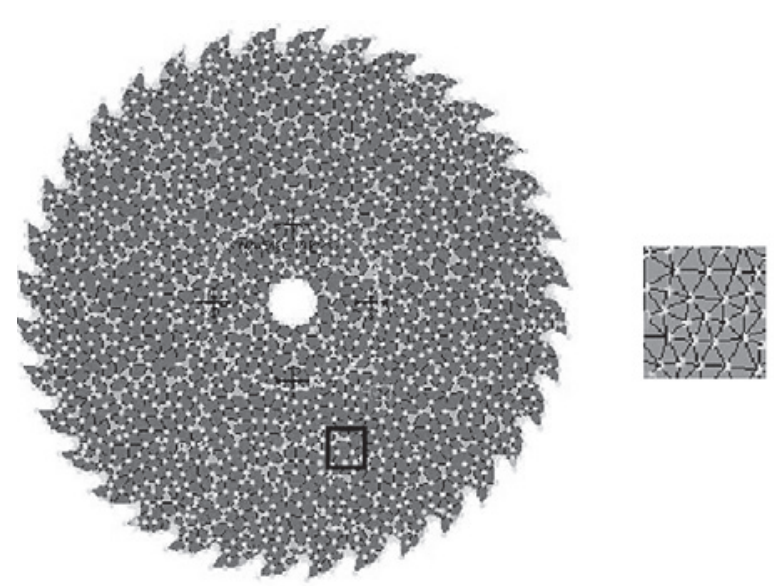

Figure 2 Mesh density of circular saw blade and detail Slika 2. Gustoća mreže lista kružne pile; detalj

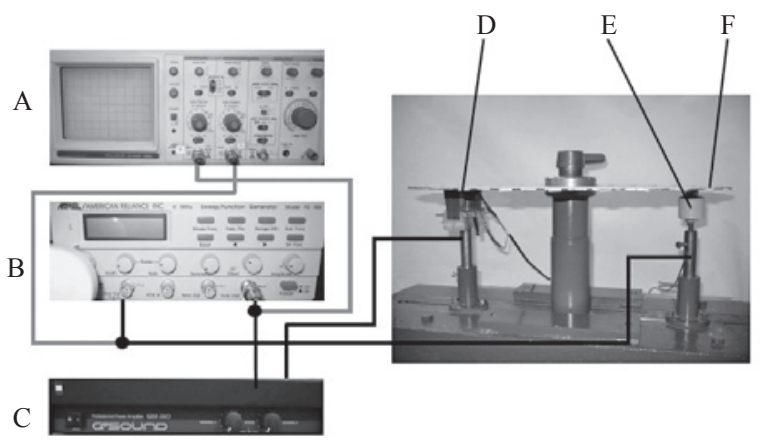

Figure 3 Scheme of experimental stand (Orłowski and Javorek, 2009); A - digital oscilloscope, B - tone generator, $\mathrm{C}$ - amplifier, D - Electromagnetic (solenoid) driver, E non-contact displacement transducer, F - circular saw blade Slika 3. Shema provedbe eksperimenta (Orłowski and Javorek, 2009.): A - digitalni osciloskop, B - ton-generator, $\mathrm{C}$ - pojačalo, D - elektromagnetski vozač, E - beskontaktni davač pomaka, $\mathrm{F}$ - list kružne pile.

\subsection{Experimental measurements}

2.3. Eksperimentalna mjerenja

Solid circular saw blade, whose parameters are presented above in Table 1, was used for experimental measurements of natural frequencies. The method (harmonic test) was presented in more detail in the paper of Siklienka and Svoreň (1997).

Natural frequencies of the non-rotating circular saw blade $f_{(n=0)}$ were measured for $n=1,2,3,4$ on an experimental stand in the Technical University in Zvolen (Fig. 3).

\section{RESULTS AND DISCUSSION} 3. RESULTATI I DISKUSIJA

In the next paragraph, mathematical and experimental results are presented in the same sequence as in paragraph Material and Methods. The calculated values of natural frequencies determined by the Bessel function are shown in Table 2.

Table 2 Calculation values of natural frequencies determined by Bessel functions (B.F.)

Tablica 2. Izračunane vrijednosti vlastitih frekvencija Besselovim funkcijama

\begin{tabular}{|c|c|c|c|c|}
\hline $\mathbf{n}$ & 1 & 2 & 3 & 4 \\
\hline $\boldsymbol{f}, \mathrm{Hz}$ & 147 & 179 & 297.6 & 500.5 \\
\hline
\end{tabular}

Leopold and Münz (1992) showed that the type (shell/solid) and number of elements had no significant influence on calculation accuracy of natural frequencies of circular saw blade. Our results confirm the same (see the values in Table 3 and 4).

Table 3 and 4 show two very similar frequency values for $n=1$. These values of natural frequency of cosine and sine components were called split mode by Yu and Mote (1987).

When comparing values in different columns (Shell 5) and (Shell 20), i.e. for maximum and minimum density of mesh, the difference is practically neg- 
Table 3 Calculated values of natural frequencies determined by modal analysis with shell elements

Tablica 3. Izračunane vrijednosti vlastitih frekvencija primjenom modalne analize s ravninskim elementima

\begin{tabular}{|c|c|c|c|}
\hline \multirow{2}{*}{$\boldsymbol{n}$} & Shell 5 & Shell 10 & Shell 20 \\
\cline { 2 - 4 } & $f, \mathrm{~Hz}$ & $f, \mathrm{~Hz}$ & $f, \mathrm{~Hz}$ \\
\hline \multirow{2}{*}{1} & \multirow{2}{*}{147.57} & 147.59 & 147.56 \\
\cline { 3 - 4 } & & 149.16 & 149.14 \\
\hline 2 & 172.81 & 172.83 & 172.8 \\
\hline 3 & 271.36 & 271.4 & 271.36 \\
\hline 4 & 439.45 & 439.52 & 439.46 \\
\hline
\end{tabular}

ligible (see Fig. 4), but time of computing for Shell 20 is shorter than for Shell 5.

The modal analysis with solid elements was made on a circular saw blade with the element size of $10 \mathrm{~mm}$ (Solid 10) and $20 \mathrm{~mm}$ (Solid 20). The calcu-
Table 4 Calculated values of natural frequencies determined by modal analysis with solid elements

Tablica 4. Izračunane vrijednosti vlastitih frekvencija primjenom modalne analize s volumenskim elementima

\begin{tabular}{|c|c|c|}
\hline \multirow{2}{*}{$n$} & solid_10 & solid_20 \\
\cline { 2 - 3 } & $f, \mathrm{~Hz}$ & $f, \mathrm{~Hz}$ \\
\hline \multirow{2}{*}{1} & 147.35 & 147.08 \\
\cline { 2 - 3 } & 148.91 & 148.68 \\
\hline 2 & 172.68 & 172.37 \\
\hline 3 & 271.69 & 271.2 \\
\hline 4 & 440.38 & 439.63 \\
\hline
\end{tabular}

lated results are shown in Table 4, and graphically in Figure 5.

The values of natural frequencies, which were determined by experimental measuring, (using the apparatus in Fig. 3), are shown in Table 5. The criteria for

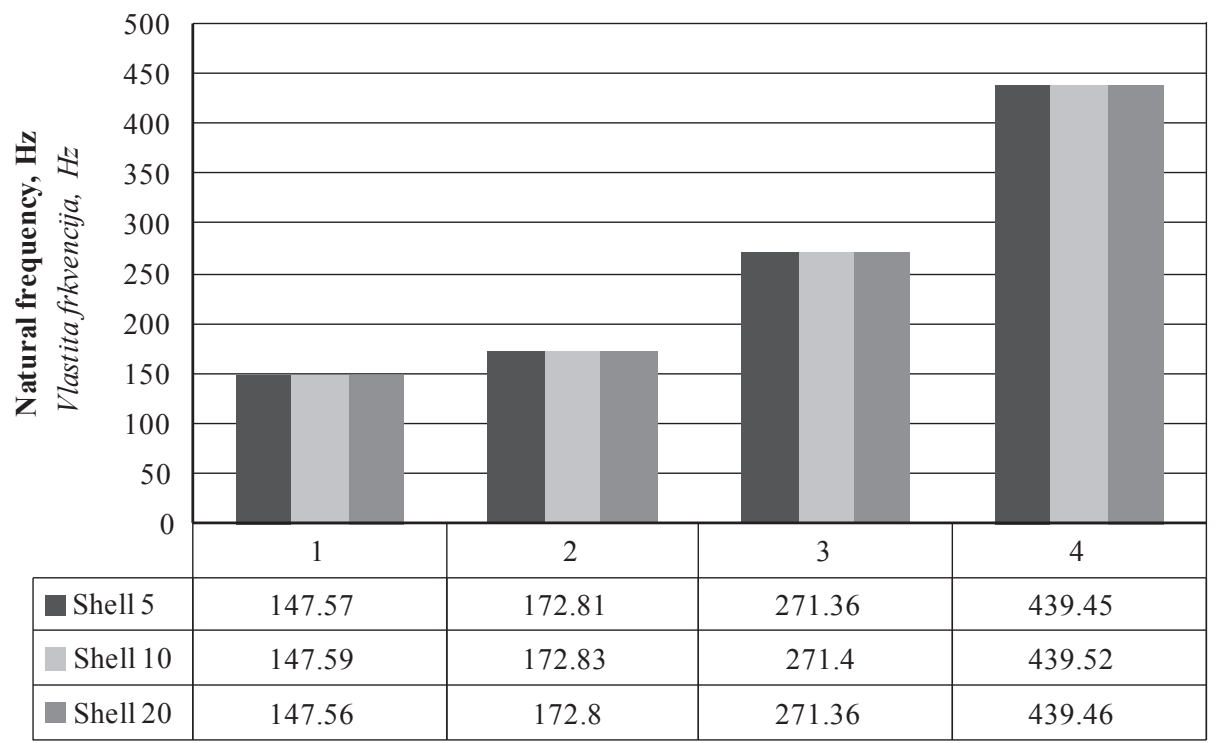

Figure 4 Values of natural frequencies determined by modal analysis of circular saw blade with shell elements Slika 4. Vrijednosti vlastitih frekvencija dobivene primjenom modalne analize kružne pile s ravninskim elementima

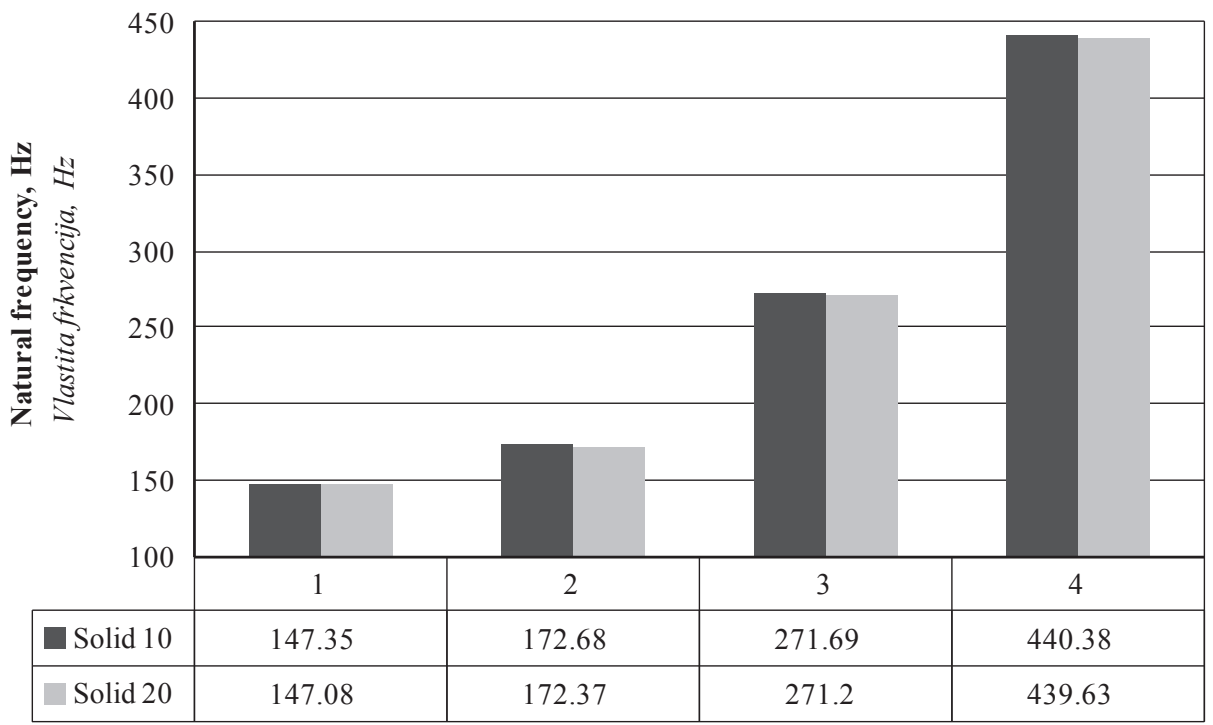

Figure 5 Values of natural frequencies determined by modal analysis of circular saw blade with solid elements Slika 5. Vrijednosti vlastitih frekvencija dobivenih modalnom analizom kružne pile s volumenskim elementima 


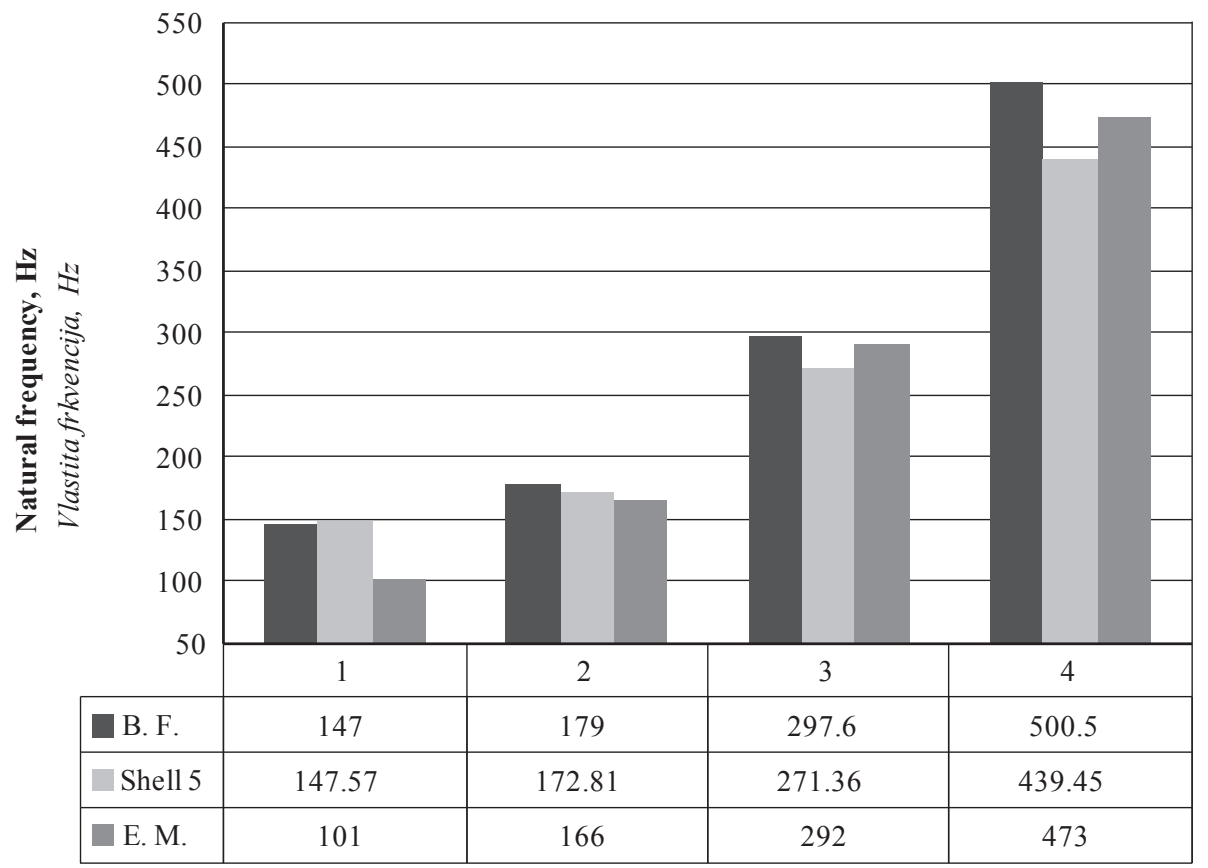

Figure 6 Comparison of natural frequencies determined by different methods

Slika 6. Usporedba vrijednosti vlastitih frekvencija lista kružne pile dobivenih različitim metodama

Table 5 Experimentally measured values of natural frequencies

Tablica 5. Eksperimentalno izmjerene vrijednosti vlastitih frekvencija

\begin{tabular}{|c|c|c|c|c|}
\hline $\boldsymbol{n}$ & 1 & 2 & 3 & 4 \\
\hline $\boldsymbol{f}, \mathrm{Hz}$ & 101 & 166 & 292 & 473 \\
\hline
\end{tabular}

accepting the searched frequency was the quality, brightness and sharpness of Chladni patterns on the tested saw disc.

As shown in Figure 6, the values of natural frequencies for $n=1$ are the same for B.F. and Shell 5 .

Values are relatively identical for $n=2$, and for $n$ $=3$ the values determined by modal analysis are pretty lower than the values determined by other two methods, which are identical. For $n=4$, the differences between values are relatively high. It could be said that the values determined by modal analysis are in accordance with the values determined by other methods used in the paper.

\section{CONCLUSIONS}

\section{ZAKLJUČCl}

On the basis of the experiments, it could be stated that:

1. Application of finite element method with various types of elements (shell/solid) and dimensions (5/ $10 / 20)$ resulted in approximate data of natural frequencies for shape modes $n=1,2,3,4$. This corresponds to the results of other authors cited in references.

2. The values of natural frequencies determined by all three methods are acceptable. Considering the difference in the values of natural frequencies, for $n=1$, between values determined by experimental method and with the use of Bessel functions, and between values determined by experimental method and by finite element methods, it seems that the mathematical apparatus is not able to solve exactly the state of thin plate (saw disc is thin plate).

3. The good conformity of the three results shows that manufacturers could use the available software that can simulate relatively exactly the behaviour of the studied phenomena - in our case natural frequencies and other parameters in the real operating conditions. The use of software will save the time and money of manufacturers for production of circular saw blades and their testing.

\section{REFERENCES}

5. LITERATURA

1. Benhao, J.; Minqi, S.; Yeqian, G.; Zheng, W.; Nanfeng, Z., 2009: Overspeed Test of Circular Saw Blade. In: Proceedings $19^{\text {th }}$ International Wood Machining Seminar, Nanjing, 21. - 23. October, 228-233.

2. Ekevad, M.; Cristóvão, L.: Grönlund, A., 2009: Different methods for monitoring flatness and tensioning in circular - saw blades. In: Proceedings $19^{\text {th }}$ International Wood Machining Seminar, Nanjing, 21. - 23. October, 121131.

3. Gogu, G., 1988: Berechnung der Eigenfreguenzen von Kreissägeblättern mit der Finite-Element-Methode. Holz als Roh- und Werkstoff, 46 (3): 91-100. http://dx.doi.org/10.1007/BF02612051

4. Holpyen, S., 1987: Vibrations and natural frequencies of angular slot circular saws. Holz als Roh- und Werkstoff, 45 (3): 101-104.

5. Javorek, L'; Murín, L.; Svoreň J., 2010: Effect of shape of compensating slots in the body of a circular saw blade on noise level in the cutting process. ProLigno - Scientific Journal in the field of wood engineering, 6 (4): 5-12. 
6. Kirshoff, G. R., 1982: Gesammelte Abhandlungen. Leipzig, 237-285.

7. Leopold, J.; Münz, V. V., 1992: Dynamische und statische Untersuchungen von Kreissägeblättern mittels der Finite-Elemente-Methode. Holzbearbeitung, 6: 52-56.

8. Michna, S.; Svoreň, J., 2007: Application of CAD, CAE with FEM for estimation ranges of values of critical rotational speed of Circular saw blades. Acta Facultatis Technicae, 9 (1): 201-206.

9. Mote, C. D., 1965: Free Vibration of Initially Stressed Circular Disk. Journal of Engineering for Industry, 5: 258-264. http://dx.doi.org/10.1115/1.3670808

10. Nishio, S.; Marui, E., 1996: Effects of Slots on Lateral Vibration of Circular Saw Blade. Proccedings of Tenth Wood Maschining Seminar, 159-164. http://dx.doi.org/10.1016/0890-6955(95)00088-7

11. Orlowski, K.; Sandak, J.; Tanaka, Ch., 2007: The critical rotational speed of circular saw: Simple measurement method and its practical implementation. Journal of Wood Science 53 (5): 388-393. http://dx.doi.org/10.1007/s10086-006-0873-5

12. Orłowski K.; Javorek, L., 2009: Limitations of the Chladni patterns method of the determination of circular saw blade critical rotational speed. In.: Annals Warsaw University of Life Science - Forestry and Wood Technology, 69: 152-157.

13. Pahlitzsch, G.; Rowinski, B., 1966: Über der Swingungsverhalten von Kreissägeblättern. 2. Mitteilung: Ermittlung und Auswirkungen der Kritische Drehzahlen und Eigenfreguenzen der Sägeblätter. Holz als Roh-und Werkstoff, 24 (8): 341-346. http://dx.doi.org/10.1007/BF02619215

14. Schajer, G. S.; Mote, C. D., 1983: Analysis of roll tensioning and its influence on circular saw stability. Wood Sci. Technol., 17 (4): 287-302. http://dx.doi.org/10.1007/BF00349916
15. Siklienka, M.; Svoreň, J., 1997: Frekvencie vlastných tvarov kmitov pílových kotúčov pri statickom kmitaní. TU Zvolen, Scientific studies.

16. Southwell, R. V., 1922: On the free transverse vibrations of a uniform circular disc clamped at its centre, and on the effects of rotation. Proceedings of the Royal Society of London, Series A 101. http://dx.doi.org/10.1098/rspa.1922.0032

17. Stakhiev, Y. M., 1970: Rezonansnyje kolebanija diskovych pil. Izv. VUZ. Lesnoj žurnal, 13 (5): 78-84.

18. Stakhiev, Y. M., 1998: Research on circular saw vibration in Russia: From theory and experiment to the needs of industry. Holz als Roh- und Werkstoff, 56 (2): 131-137. http://dx.doi.org/10.1007/s001070050284

19. Stakhiev, Y. M., 2000: Today and tomorrow circular saw blades: Russian version. Holz als Roh- und Werkstoff, 58 (4): 229-240. http://dx.doi.org/10.1007/s001070050417

20. Veselý, P.; Kopecký, Z.; Hejmal, Z.; Pokorný, P., 2012: Diagnostics of circular saw blade vibration by displacement sensors. Drvna industrija, 63 (2): 81-86. http://dx.doi.org/10.5552/drind.2012.1130

21. Yu, R. C.; Mote, C. D., 1987: Vibration of Circular saws Containing Slots. Holz als Roh- und Werkstoff, 45 (4): 155-160. http://dx.doi.org/10.1007/BF02627571

\section{Corresponding address:}

\section{Assoc. Prof. Dr. JÁN SVOREŇ}

Faculty of Environmental and

Manufacturing Technology

Technical University in Zvolen

T. G. Masaryka 24

96053 Zvolen, SLOVAK REPUBLIC

e-mail: svoreň@tuzvo.sk 